\title{
Original article \\ Opinion of 3rd year medical students about assessment system in 1st professional MBBS examination in Bangladesh
}

Asaduzzaman AKM, ${ }^{1}$ Aloy NM, ${ }^{2}$ Aich N 3

\begin{abstract}
This descriptive cross-sectional study was carried out on 384 third year medical students from 6 government and 6 non-government medical colleges to find out the opinion regarding newly introduced assessment system in the 1st professional MBBS examination which was held in January 2012. It was found that majority (75\%) of the respondents expressed their satisfaction with the newly introduced assessment system. Ninety one percent students opined that short answer question in written examination had inclined students to understand content rather than memorization. Eighty nine percent and eighty six percent respondents expressed their opinion in favor of MCQ and objective structured practical examination respectively. Majority (82.03\%) students opined that inclusion of structured oral examination (SOE) instead of traditional oral exam was better. Nearly $87 \%$ respondents thought that adding of a certain percentage of mark of formative assessment was a positive initiative. On the other hand, 35\% students felt that examination phobia in oral or viva is not reduced by introducing SOE, 27\% believed that all examination are not judged in same standard by the examiners by means of OSPE and $24 \%$ respondents believed that result of SOE depends, to some extent, upon examiners desire and intension. So, it revealed that the new assessment method is not implemented properly, teachers were not trained accordingly and students were not aware about the new assessment method.
\end{abstract}

Key words: Assessment, medical education, professional examination, MBBS, Bangladesh

1. Dr AKM Asaduzzaman, Assistant Professor Centre for Medical Education

Dhaka, Bangladesh.

Email : asadcme@gmail.com

2. *Dr Nirjhar Mandal Aloy, Lecturer Department of Anatomy, Green Life Medical

College, Dhaka, Bangladesh.

Email: nirjharaloy@gmail.com

3. Dr Nibedita Aich, Lecturer

Department of Biochemistry

Ad-Din Women's Medical College

Dhaka, Bangladesh.

*For correspondence

\section{Introduction}

Assessment of student is done to check whether they will be able to do the job reasonably well. Assessment is one of the important parts of any education and it is much more important how the assessment system is being used. Assessment is a matter of measurement and it has a powerful influence over learning. ${ }^{1}$ One of the most important responsibilities of teachers is to find out how much students have learned and assessment is the process to find out that. ${ }^{2}$ Assessment can be used to guide the students about which topics and skills they need to learn more. It can also guide the teachers about which part of the course has been successful and which part needs to be improved. ${ }^{2}$

A medical teacher should answer five questions in relation to assessment. The questions are 1 . What should be assessed? 2. How should be assessed? 3. Why it should be assessed? 4. When it should be assessed? 5. Who should carry out the assessment? 3

When an examiner is going to assess students, he should think about above mentioned questions in mind. A number of factors affecting learning like quality of teaching, approach to learning, availability and access of resources etc. The most powerful single influence on learning is probably the assessment system, which is used. ${ }^{4}$

Assessment techniques have been refined in most medical schools. The refinements are a consequence of research findings, which question the validity and objectivity of the conventional assessment techniques. Objective examinations have replaced most of the essay and oral examinations. ${ }^{5}$ Oral examinations are traditionally an integral part of the assessment. It involves personal contact between the examiners and the students following serious limitation : (a) it lacks objectivity (b) time consuming in nature and (c) the questions are not standardized. ${ }^{6,7}$ There is a notable changes in written examination and also in traditional oral and practical examination in each subjects in the newly introduced curriculum which was introduced in March 2003. The changes are as follows- a) $10 \%$ marks of written examination of each paper of each subject is allocated for formative assessment, b) $20 \%$ marks are allocated for MCQ for each paper, c) 70\% marks are allocated for 
Short answer question (SAQ), d) traditional oral examination has been replaced by structured oral examination (SOE) and e) in practice examination-objective structured practical examination (OSPE) is introduced.

To improve the quality of the assessment, it is very important to find out the problems in the process of newly introduced assessment system. This study was designed to explore the present status of newly introduced assessment system in the first professional examination conducted by the teachers in different medical colleges. It is expected that, this study will help to explore the strengths and weakness in favor of the newly introduced assessment system and will help teachers, examiners and administrators to overcome the lacking for better outcome of educational process.

\section{Methods}

This cross sectional study was carried out among the 3rd year medical students who appeared in the newly introduced assessment system in 1st professional MBBS examination in January 2012. Three hundred eighty four new third year medical students from six government and six non-government medical colleges were purposively selected and interviewed. Questionnaire were distributed among the medical students and answered by their own. Before distribution of a questionnaire the purpose of the study was clearly explained to the students, so that they can answer the questions to the best of their knowledge. After collection of the data, questionnaire were checked and verified to reduce errors and inconsistencies. Statistical analyses of the results were done by using windows based computer software devised with Statistical Packages for Social Sciences (SPSS-17).

Ehical approval was given by the Centre for Medical Education, Dhaka. Informed consent was obtained from each participant and anonymity was kept. Permission was taken from the respective Deans and Principal's to conduct the study.

\section{Results}

Among the respondents, $98.7 \%$ students mentioned that short answer question in written exam are better than essay type questions where as only $1.30 \%$ students were against the statement.(Table-I) It also shows $87.76 \%$ of the respondents thought that inclusion of MCQ in written exam is better whereas $12 \%$ students thought that it was not good. $82.03 \%$ students mentioned that inclusion of structured oral examination in new system is better whereas $17.97 \%$ were against the statement. In relation to OSPE, $86.20 \%$ students opined that inclusion of OSPE in new assessment system is better whereas 13\% student thought that it was not good.(Table-I) Among the 384 students, $86.72 \%$ were in favor of the opinion that a

Table-I: Strengths of the new assessment method as to the best of their perception identified by the students

\begin{tabular}{lccc}
\hline \multicolumn{1}{c}{ Opinion } & Yes & No & Total \\
\hline Satisfied with the new assessment system & 288 & 96 & 384 \\
& $(75 \%)$ & $(25 \%)$ & $(100 \%)$ \\
$\begin{array}{l}\text { Short answer questions (SAQ) are better than essay } \\
\text { type questions }\end{array}$ & 379 & 05 & 384 \\
Opinion regarding inclusion of MCQ in written & $(98.7 \%)$ & $(1.30 \%)$ & $(100 \%)$ \\
exam & 337 & 47 & 384 \\
$\begin{array}{l}\text { Opinion regarding inclusion of the structured oral } \\
\text { examination (SOE) in the new assessment system: }\end{array}$ & $(87.76 \%)$ & $(12.24 \%)$ & $(100 \%)$ \\
$\begin{array}{l}\text { Opinion regarding inclusion of the objective } \\
\text { structured practical examination (OSPE) in the new } \\
\text { assessment system }\end{array}$ & 315 & 69 & 384 \\
$\begin{array}{l}\text { Opinion regarding adding the marks of formative } \\
\text { assessment to the final examination }\end{array}$ & $(82.03 \%)$ & $(17.97 \%)$ & $(100 \%)$ \\
\hline
\end{tabular}


certain percentage of formative assessment mark should be added to the final examination whereas $13.28 \%$ were against the opinion. (Table-I) $59.90 \%$ of the respondents agreed with the opinion that result of structured oral examination (SOE) is not depended on the desire of examiner, $23.69 \%$ of respondents disagreed with the opinion and $16.41 \%$ were undecided. $42.19 \%$ of the respondents agreed with the opinion that it is possible to judge all students in the same standard in SOE, $44.27 \%$ of respondents disagreed and $13.54 \%$ were undecided. $64.58 \%$ of the respondents agreed with the opinion that all students have to answer equal number of questions in SOE, $27.61 \%$ disagreed and rest $7.81 \%$ was undecided.
Regarding SOE, 48.96\% respondents agreed with the opinion that students fear regarding oral or viva examination is reduced by introducing SOE where as $34.37 \%$ disagreed and $16.67 \%$ could not make any decision in this question. (Table-II)

However, $61.20 \%$ of the respondents agreed with the opinion that it is possible to judge all necessary practical skills in OSPE, $21.61 \%$ disagreed with the opinion and $17.19 \%$ were undecided. $62.24 \%$ of the students agreed with the opinion that all students are judged in a same standard by all examiners by means of OSPE, $26.30 \%$ disagreed and $11.46 \%$ were undecided. (Table-II)

Table-II: Distribution of the respondents by their opinion on SOE \& OSPE

\begin{tabular}{|c|c|c|c|c|c|c|}
\hline Opinion & $\begin{array}{l}\text { Strongly } \\
\text { agree }\end{array}$ & Agree & Undecided & Disagree & $\begin{array}{l}\text { Strongly } \\
\text { disagree }\end{array}$ & Total \\
\hline \multicolumn{7}{|l|}{ Structured oral examination } \\
\hline $\begin{array}{l}\text { Result does not depend } \\
\text { on the disposition of the } \\
\text { examiner }\end{array}$ & $\begin{array}{c}73 \\
(19.01 \%)\end{array}$ & $\begin{array}{c}157 \\
(40.89 \%)\end{array}$ & $\begin{array}{c}63 \\
(16.41 \%)\end{array}$ & $\begin{array}{c}52 \\
(13.54 \%)\end{array}$ & $\begin{array}{c}39 \\
(10.15 \%)\end{array}$ & $\begin{array}{c}384 \\
(100 \%)\end{array}$ \\
\hline $\begin{array}{l}\text { All students can be } \\
\text { judged equally }\end{array}$ & $\begin{array}{c}45 \\
(11.72 \%)\end{array}$ & $\begin{array}{c}117 \\
(30.47 \%)\end{array}$ & $\begin{array}{c}52 \\
(13.54 \%)\end{array}$ & $\begin{array}{c}126 \\
(32.81 \%)\end{array}$ & $\begin{array}{c}44 \\
(11.46 \%)\end{array}$ & $\begin{array}{c}384 \\
(100 \%)\end{array}$ \\
\hline $\begin{array}{l}\text { All students have to } \\
\text { answer an equal number } \\
\text { of questions }\end{array}$ & $\begin{array}{c}68 \\
(17.71 \%)\end{array}$ & $\begin{array}{c}180 \\
(46.87 \%)\end{array}$ & $\begin{array}{c}30 \\
(7.81 \%)\end{array}$ & $\begin{array}{c}67 \\
(17.45 \%)\end{array}$ & $\begin{array}{c}39 \\
(10.16 \%)\end{array}$ & $\begin{array}{c}384 \\
(100 \%)\end{array}$ \\
\hline $\begin{array}{l}\text { Students' phobia of } \\
\text { examination is reduced }\end{array}$ & $\begin{array}{c}43 \\
(11.20 \%)\end{array}$ & $\begin{array}{c}145 \\
(37.76 \%)\end{array}$ & $\begin{array}{c}64 \\
(16.76 \%)\end{array}$ & $\begin{array}{c}78 \\
(20.31 \%)\end{array}$ & $\begin{array}{c}54 \\
(14.06 \%)\end{array}$ & $\begin{array}{c}384 \\
(100 \%)\end{array}$ \\
\hline \multicolumn{7}{|l|}{$\begin{array}{l}\text { Objective structured practical } \\
\text { examination }\end{array}$} \\
\hline $\begin{array}{l}\text { All the necessary practical } \\
\text { skills can be judged }\end{array}$ & $\begin{array}{c}68 \\
(17.71 \%)\end{array}$ & $\begin{array}{c}167 \\
(43.49 \%)\end{array}$ & $\begin{array}{c}66 \\
(17.19 \%)\end{array}$ & $\begin{array}{c}68 \\
(17.71 \%)\end{array}$ & $\begin{array}{c}15 \\
(3.90 \%)\end{array}$ & $\begin{array}{c}384 \\
(100 \%)\end{array}$ \\
\hline $\begin{array}{l}\text { All students can be judged } \\
\text { equally }\end{array}$ & $\begin{array}{c}51 \\
(13.28 \%)\end{array}$ & $\begin{array}{c}188 \\
(48.96 \%)\end{array}$ & $\begin{array}{c}44 \\
(11.46 \%)\end{array}$ & $\begin{array}{c}75 \\
(19.53 \%)\end{array}$ & $\begin{array}{c}26 \\
(6.77 \%)\end{array}$ & $\begin{array}{c}384 \\
(100 \%)\end{array}$ \\
\hline
\end{tabular}

It is showed that $90.89 \%$ of the respondents agreed with the opinion that in new assessment system, short answer question (SAQ) in written exam inclined students to understand the content rather than memorizing, where as $5.99 \%$ disagreed with that opinion and 3\% were undecided. $8.59 \%$ of the respondents agreed with the opinion that it is easier to pass written examination by memorizing a few number of questions answers in new assessment method and $87.77 \%$ disagreed with that opinion. $3.64 \%$ could not make any decision in this question. (Table-III)

In relation to formative assessment, $89.84 \%$ of the students agreed with the opinion that the marks of formative assessment on daily attendance in the class make students more interested in class attendant, 5.99\% of respondents disagreed and rest $4.17 \%$ were undecided. (Table-III) 
Table-III: Distribution of the respondents by their opinion on written examination and formative assessment

\begin{tabular}{|c|c|c|c|c|c|c|}
\hline Opinion & $\begin{array}{l}\text { Strongly } \\
\text { agree }\end{array}$ & Agree & Undecided & Disagree & $\begin{array}{l}\text { Strongly } \\
\text { disagree }\end{array}$ & Total \\
\hline \multicolumn{7}{|l|}{ SAQ in written examination } \\
\hline $\begin{array}{l}\text { Incline students } \\
\text { understand the content } \\
\text { rather than memorizing }\end{array}$ & $\begin{array}{c}173 \\
(45.05 \%)\end{array}$ & $\begin{array}{c}176 \\
(45.84 \%)\end{array}$ & $\begin{array}{c}12 \\
(3.12 \%)\end{array}$ & $\begin{array}{c}15 \\
(3.91 \%)\end{array}$ & $\begin{array}{c}08 \\
(2.08 \%)\end{array}$ & $\begin{array}{c}384 \\
(100 \%)\end{array}$ \\
\hline $\begin{array}{l}\text { It easier to pass a written } \\
\text { examination }\end{array}$ & $\begin{array}{c}09 \\
(2.34 \%)\end{array}$ & $\begin{array}{c}24 \\
(6.25 \%)\end{array}$ & $\begin{array}{c}14 \\
(3.64 \%)\end{array}$ & $\begin{array}{c}132 \\
(34.38 \%)\end{array}$ & $\begin{array}{c}205 \\
(53.39 \%)\end{array}$ & $\begin{array}{c}384 \\
(100 \%)\end{array}$ \\
\hline \multicolumn{7}{|l|}{ Formative assessment } \\
\hline $\begin{array}{l}\text { Considering the marks } \\
\text { of daily attendance make } \\
\text { students more interested } \\
\text { in class }\end{array}$ & $\begin{array}{c}154 \\
(40.10 \%)\end{array}$ & $\begin{array}{c}191 \\
(49.74 \%)\end{array}$ & $\begin{array}{c}16 \\
(4.17 \%)\end{array}$ & $\begin{array}{c}12 \\
(3.13 \%)\end{array}$ & $\begin{array}{c}11 \\
(2.86 \%)\end{array}$ & $\begin{array}{c}384 \\
(100 \%)\end{array}$ \\
\hline
\end{tabular}

\section{Discussion}

This cross sectional study was conducted among the 3 rd year students, who had appeared the new assessment system in 1st professional MBBS examination January, 2012. The study was conducted to assess the opinion about the newly introduced assessment system in 1 st professional (summative) MBBS examination according to the new curriculum which is implemented.

It was found that majority of the respondent expressed their satisfaction $(75 \%)$ with the newly introduced assessment system. Overwhelming $98.70 \%$ students have opined that SAQ is better than traditional essay type questions. Majority (90.89\%) also opined that SAQ in written examination inclined students to understand the content rather than memorization. Majority $(88 \%)$ of them think that in new assessment system, it is not possible to pass written examination by memorizing the answer of a few number of questions.

They also expressed their concern about SOE which was introduced instead of traditional viva examination. The study reveals that inclusion of SOE instead of viva exam is better $(82 \%)$ which is stated by the respondents. They (59.9\%) also expressed that the result of SOE did not depend on examiners desire and intention in many cases. Still a reasonably good number of respondents (23.69\%) disagree with the opinion and $16.4 \%$ had doubt in this concern. Among the study subjects, $42.19 \%$ of the respondents agreed with the opinion that it is possible to judge all students equally in SOE. However, $44.27 \%$ of respondents disagreed and $13.54 \%$ were undecided. This may be due to lacking in implementation of the SOE perfectly, such as answering of equal number of questions by all students. $48.96 \%$ respondents agreed with the opinion that students fear regarding oral/viva examination is reduced by introducing SOE, $34.37 \%$ disagreed and $16.67 \%$ were undecided.

Opinion regarding inclusion of OSPE, majority of the respondents $(86 \%)$ was in favour of OSPE. $61.20 \%$ students felt that it is possible to judge all necessary practical skill in OSPE. $62.24 \%$ of the students agreed with the opinion that all students are judged in a same standard by all examiners by means of OSPE. Majority of the respondents $(86.72 \%)$ also opined that adding of a certain percentage of marks of formative assessment in final examination is better. Students will give importance to formative assessment and it will increase their interest towards class attendance.

From the overall study findings it is clear that majority of the students were in favour to new assessment system. But still the study also revealed that the newly introduced assessment system has a number of short comings which need attention by teachers and policy makers. New assessment system must be completely implemented in all medical colleges. There should be a regular monitoring system of the examination process in different medical colleges. SOE and OSPE should not be held in the same day but in two separate days. Rules and regulation of new assessment system will be supervised by the experts those who are the representative of the universities. There should be exclusive training course in the Centre for Medical Education (CME) especially on assessment methods. Teachers should aware the students regularly regarding the new assessment procedure especially in formative assessment. 


\section{References}

1. Sood R, Singh T. Assessment in medical education: evolving perspectives and contemporary trends. Natl Med J India. 2012 Nov-Dec;25(6):357-64.

2. Abbat FR. Teaching for Better Learning. 1980. World Health Organization, Geneva.

3. Crooks TJ. The Impact of Classroom Evaluation Practices on Students. Review of Educational Research. 1988; 58 : 438-81.

4. Harden RM. ASME Medical Education Booklet, No-20, Ten questtions to ask when planning a course or curriculum. Medical Education. 1986; 20:356.
5. Gibbs G. Improving The Quality of Student's Learning, Technical and Educational Services Ltd, Bristol. 1992

6. Jayawickramarajah P. Curriculum Reform in medical School, Bahrain, Medical Bullein. 1986;47:47-53

7. Srinivasa DK and Kumar S. Assessment of Students, Essentials of Medical Education. Health learning materials Centre, Institute of Medicine, Tribhuvan, University of Kathmandu, Nepal, 1996. 